\title{
CREATIVE CITIES AND KNOWLEDGE MANAGEMENT APPROACH TO CULTURE-BASED URBAN REGENERATION IN SLOVAKIA: A MODEL
}

\author{
Mária Tajtáková*, Mária Olejárová \\ School of Management / City University of Seattle Programs, Bratislava, Slovakia \\ *E-mail of corresponding author: mtajtakova@vsm.sk
}

\begin{abstract}
Resume
The term "Creative City" emerged in the 90s of the 20th century reflecting the trend of transforming post-industrial cities into new creative urban centres - bases for knowledge intensive firms, highly-skilled workers and major cultural assets. The concept of culture-based urban regeneration describes a scheme where culture is purposely employed as a vehicle for an overall urban and social revitalization. The paper addresses innovative processes within culture-based urban regeneration projects in three Slovak cities - Bratislava, Zilina and Kosice - under the concept of creative city. The focus is on the implementation of a tailor-made multi-factor knowledge management model with the aim of exploring the knowledge management practices in urban development projects dealing with the adaptive re-use of industrial and cultural heritage based on the non-profit bottom-up initiatives.
\end{abstract}

Available online: https://doi.org/10.26552/com.C.2021.4.G25-G37

\section{Article info}

Received 5 September 2020

Accepted 18 January 2021

Online 25 June 2021

\section{Keywords:}

creative city, culture-based urban regeneration, adaptive re-use, knowledge management, model

ISSN 1335-4205 (print version)

ISSN 2585-7878 (online version)

\section{Introduction}

In the last decades knowledge has been increasingly recognized as the core factor of a new socio-economic model called the "Knowledge Economy". Within this paradigm the knowledge is considered to be the main source of economic progress in a nowadays society. It generates innovation, which enhances the creation of new socio-economic values and further development [1]. Sousa [2] emphasizes the recognition of knowledge as the fundamental driver of sustainable competitive and collaborative advantage and a major breakthrough in management thinking. In addition, Florida [3] advocates knowledge networks and highly skilled labour forces in creative industries as key factors driving the economic and urban growth and highlights the birth of a parallel socio-economic phenomenon - the "Creative Economy".

The creative economy is based on creative industries recognizing creative labour as a vital force for the future development. Levickaite and Reimeris [4] summarized major concepts of this new phenomenon: (1) Creative industries - based on John Howkins' creative economy [5] encompassing 15 sectors such as advertising, architecture, art, crafts, design, designer fashion, film/ video, music, performing arts, publishing, scientific research and technology, software, toys/games, TV/radio and computer games; (2) Creative class - defined by Florida [3] as people working in the creative industries;
(3) Economic properties - suggested by Caves [6] as a new logic of economic behaviour taking into account intrinsic factors like personal fulfilment, the variability of skills and talents and unpredictability; (4) Creative identities - described by Hartley [7] as vanishing borders between the creator, the vendor and the user of creative services; and (5) Creative cities - introduced by Landry and Bianchini [8] as a model of urban development based on culture and creative industries.

As emphasized by Renz [9], creativity, in the sense of Florida [3] and Landry and Bianchini [8], is not reserved to artists, but is a feature of all the occupations that are representing an ideas-driven knowledge economy. In this respect, the report entitled Culture, the heart of the knowledge-based economy, prepared by the European Cultural Parliament Lisbon Agenda Research Group [10], highlighted the strategic use of culture that goes beyond the arts and heritage and creates a new driving force for change and innovation in different domains of society. The culture has a potential to inject new ideas into business and the economy, it inspires communities to promote new ways of participation, responsibility and cohesion and re-energizes education. Furthermore, the communication of the European Commission named Unlocking the Potential of Cultural and Creative Industries (CCI) [11], recognised the CCI as one of Europe's most dynamic sectors catalyzing the spill-over effects on a wide range of economic and social contexts. 
It is assumed that knowledge and creative economy are the two major forces that influence current economic and social development showing important intersections and possessing a significant potential of achieving a synergic effect. The paper addresses concurrent influences of knowledge and creative economy on innovative processes within the culture-based urban regeneration projects in Slovakia under the concept of creative city. Although cities are bases for knowledgeintensive activities, as well as centres of major cultural assets, only a limited attention [12-15] has been paid to the knowledge transfer within the culture-based urban regeneration projects. The focus here is on the implementation of a tailor-made multi-factor knowledge management model within the urban revitalization initiatives in three Slovak cities - Bratislava, Zilina and Kosice. Authors' aim is to explore the knowledge transfer and related managerial practices in urban development projects, dealing with the adaptive re-use of industrial and cultural heritage, based on non-profit bottom-up initiatives.

\section{Creative cities and knowledge management: conceptual framework}

The concept of the "Creative City" emerged in the $90 \mathrm{~s}$ of the 20th century thanks to publications such as The creative city by Landry and Bianchini [8], The cultural economy of cities by Scott [16] and later on, Cities and creative class by Florida [17]. These works introduced a new way of thinking about the interrelationship between culture and a place. Culture has been understood as a "way of doing", which is typical for a particular location and thus determines its comparative advantage in the production of specialised goods and services [18].

The new perspective highlights a city as a place of opportunities suggesting that people living in it can respond to challenges of urban life with their creativity, as long as, the city provides conditions allowing them to do so [8]. Florida [17] emphasizes the economic value of human creativity in the city and proposes a three Ts concept for the economic growth - technology, talent and tolerance - stressing the important role of cities in bringing these three factors together.

Rodrigues and Franco [19] synthetized definition of creative cities as those that "advocate socio-cultural, economic and political changes and are characterized by diversity, openness, tolerance, the presence of a creative class and high cultural dynamism". Power and Scott [20] claimed that the creative cities show an intelligent strategy by joining their economic and urban strategies with culture. In view of the knowledge economy, cities being bases for knowledge intensive firms and institutions (such as universities, research centres or the cultural industries) possess a new strategic importance [8]. It is estimated that $54 \%$ of the world population (3.7 billion people) live in urban areas and this percentage is expected to grow up to $73 \%$ (5 billion) by 2030 [21].

From the development perspective, cities have been defined as dynamic systems, which flourish, stagnate and decline as a result of the interactions between the main actors in the urban arena: households, firms and the government [22]. According to Borg and Russo [18], the dynamism of the system is determined by technological progress, by changes in regulations and regimes (e.g. liberalisation of world markets and European integration) and by evolution in socio-economic factors, such as taste, education and demographics. In this regard, Scott [16] highlights a particular role of local culture in shaping the nature of intra-urban economic activity, which becomes a dynamic element of the culture-generation and innovative capacities of given places.

Stern [23] points out that places with high concentrations of cultural organizations and/or access to arts activities are more likely to undergo economic revitalization and to overcome barriers relating to class and ethnicity. Similarly, Shang-Ying Chen [24] argues that the more concerns on culture/creative industry and cultural tourism, the more concrete interactions between culture, economic and development occur.

Culture is seen as an eminent city industry and a typical urban phenomenon [18]. However, according to Stasilius [25] most of the nowadays cities live in their transitory periods caused by the vitality of renewed globalization leading to a new urban model in which an added value of cities does not depend on what is produced but on the intellectual capital applied to processes and services. This suggests growing impact of the knowledge economy on current urban transitions.

The process of transformation of an "industrial city" into the so-called "creative city" works under the concept of culture-based urban regeneration, respectively culture-led urban development. It describes a scheme where the culture is purposely employed as a vehicle for economic grow, local community enhancement, social inclusion and cultural tourism development leading to an overall urban and social revitalization. Pastak and Kahrik [26] highlight a substantial effect of the culture-based urban regeneration on improving the physical quality of public spaces by creating arenas for social interaction and educational activities. Borg and Russo [18] identify three main impact areas of culture on urban development: (1) direct and indirect economic impacts (employment, value creation, etc.), (2) induced effects of cultural activities on the quality of a place and (3) "creative inputs" accruing to the local networks of production and creative class development.

Actually, the concept of culture-based urban development is not really new. According to Scott [16], the interpenetration of culture and economy in given places was already highlighted by Alfred Marshall in his Principles of Economics (1920) who referred to the beneficial effects of "atmosphere" on the workings of $19^{\text {th }}$ 
century industrial districts. Scott [16] argues that in the present context, atmosphere refers more than anything else to a conglomeration of cultural synergies and semiotic fields rooted in the life, work and institutional infrastructures of particular cities. On a practical level, Landry [27] encourages urban planners to change their thinking from an urban engineering approach to a creative city making agenda where good atmosphere is the priority.

The nowadays perception of culture-based urban regeneration is basically twofold: On one hand, it is regarded as a mean for improving the quality of life for local residents and social inclusion [28-31]. On the other hand, it is seen as a way of enhancing the economic status and competitive position of cities including the cultural tourism development [17, 32-33]. However, Miles and Paddison [34] argue that achieving social cohesion and economic competitiveness have been increasingly considered as parallel and interrelated goals.

The culture-based urban development and the concept of creative city have been increasingly important for the global institutional and political agenda, as well. Since 2004, the Creative Cities Network has been developed by UNESCO with the aim of promoting cooperation with and among cities that have identified creativity as a strategic factor for sustainable urban development. Up to date the network comprises 246 cities from all over the world. The only Slovak city Kosice - was included into the UNESCO Creative Cities Network in 2017 [35]. The network offers a key forum for brainstorming the role of creativity as a driver and an enabler for sustainable urban development and a platform for action and innovation towards implementing the 2030 Agenda for Sustainable Development at the city level [36].

In 2015, the European Commission established The Cultural and Creative Cities Monitor (CCC) as a tool for promoting mutual exchanges and learning between cities to boost culture-led development. It is designed to help cities to identify their strengths and opportunities, benchmark their performance and push for policies that boost their cultural, creative and innovation potential. In 2020, the second edition (mapping the year 2019) of the Cultural and Creative Cities Monitor was released showing how well 190 selected cities in 30 European countries (the EU-28 with Norway and Switzerland) perform compared to their peers. It provides evidence of the value of cultural investment and illuminates the importance of culture and creativity for cities increasingly competing on a global scale [37].

Creative cities have been selected based on their demonstrable engagement in promoting culture and creativity, from about 1000 cities in Eurostat's Urban Audit. Therefore, the cities featured in the Monitor are already top performers. Four Slovak cities - Bratislava, Nitra, Kosice and Presov - have been included into the annual evaluation by the CCC Monitor. In total, 29 indicators and their organisation into nine dimensions, three sub-indices "Cultural Vibrancy", "Creative Economy" and "Enabling Environment" and an overall index "The Cultural and Creative Cities - C3 Index" is evaluated using both quantitative and qualitative data on a yearly basis. Up to date the CCC Monitor encompasses [37]:

- 98 cities, which have been or will be European Capitals of Culture (ECoCs) up to 2019, or which have been shortlisted to become an ECoC up to 2023;

- 59 UNESCO Creative Cities (including the most recent winners in 2015) - excluding overlap with the $\mathrm{ECoC}$;

- 33 cities hosting at least two regular international cultural festivals running until at least 2015.

In 2020, the European Commission [38] launched a project named Cultural Heritage in Action as a part of the European Framework for Action on Cultural Heritage aimed at empowering cities and regions to strengthen their cultural heritage policies and initiatives as well as develop innovative solutions to preserve cultural heritage assets. One of the three key topics of the project is the adaptive re-use of heritage buildings that shall give a new use to obsolete, underused or misused buildings. In the adaptive reuse approach, rather than continuing the building's existing use through upgrades or restoring it to a specific time period, the new use is defined and adapted to the building while preserving and respecting its value and significance.

Authors assume that the crucial factor determining the success of culture-led urban development within the concept of creative city - and the factor interconnecting all three Borg and Russo's areas [18] - is the effective knowledge management. Yet, as pointed out by Porumb and Ivanova [12], knowledge distribution can be the most sensitive aspect of the knowledge management practice. Appelyard [39] emphasizes the need of understanding the mechanisms and determinants of knowledge flows in the organizational environment highlighting diverse knowledge sharing practices. The knowledge sharing is a critical element due to its role in converting individual tacit knowledge into the organization knowledge. In, addition, Martini [40] points out that knowledge sharing is becoming more essential for areas or industries that mostly depend on innovation as a competitive advantage, such as creative industries.

Therefore, a multi-factor knowledge management model is proposed, based on the SECI model to be implemented within the process of culture-led urban regeneration. The purpose of the model is to map and systematize crucial factors influencing the knowledge transfer within this particular environment and identify the most effective knowledge management practices. Authors believe that the expected economic effects, community inclusion and cultural sustainability within culture-based urban development can only be achieved in the repeated cycles of knowledge creation, externalization and sharing, storing and critical assessment. 
Table 1 Revitalization projects included into the study

\begin{tabular}{|c|c|c|c|c|c|}
\hline & project & city & original use & new use & revitalization period \\
\hline 1 & KC Dunaj & Bratislava & department store & independent cultural centre & 2010 - ongoing \\
\hline 2 & Stara trznica & Bratislava & market city hall & $\begin{array}{l}\text { market city hall \& cultural } \\
\text { centre }\end{array}$ & 2013 - ongoing \\
\hline 3 & Stanica Zariecie & Zilina & local train station & $\begin{array}{l}\text { local train station \& } \\
\text { independent cultural centre }\end{array}$ & 2003 - ongoing \\
\hline 4 & Nova synagoga & Zilina & Jewish synagogue & $\begin{array}{l}\text { cultural \& community } \\
\text { centre }\end{array}$ & 2011 - ongoing \\
\hline 5 & $\begin{array}{l}\text { IC Culture Train } \\
\text { Vysne Opatske }\end{array}$ & Kosice & $\begin{array}{l}\text { suburb community } \\
\text { centre }\end{array}$ & $\begin{array}{l}\text { independent contemporary } \\
\text { art centre }\end{array}$ & $2005-2008$ \\
\hline 6 & Tabacka Kulturfabrik & Kosice & tobacco factory & $\begin{array}{l}\text { creative cultural factory } \\
\& \text { co-working } \\
\text { incubator }\end{array}$ & 2009 - ongoing \\
\hline
\end{tabular}

\section{$3 \quad$ Methodology}

\subsection{The scope of the study}

The study consisted of six culture-based urban regeneration projects carried out in different parts of Slovakia (Table 1). All the projects represented culture-led urban regeneration activities with a common aim of transforming unused and dilapidated buildings with diverse types of original use into new cultural venues. The regeneration processes started between the years 2003 and 2013 and are partly still in progress, although the major revitalization effort has already been accomplished.

The analysed projects were located in three different cities in Slovakia representing also three different regions: Bratislava - Cultural Centre Danube (Kulturne centrum - KC Dunaj) and Market City Hall (Stara trznica); Zilina - Local Train Station ZilinaZariecie (Stanica Zilina-Zariecie) and New Synagogue (Nova synagoga); and Kosice - IC Culture Train (Vysne Opatske) and Tobacco Cultural Factory (Tabacka Kulturfabrik).

\subsection{Data and methods}

Both primary and secondary data were collected to map the knowledge management processes in the culture-led urban regeneration projects in three Slovak cities. Primary data were gathered via exploratory qualitative research using the method of semi-structured in-depth interviews. Repeated interviews with the main representatives of six culture-based urban regeneration initiatives were conducted in order to capture the larger process of knowledge conversion and transfer. Interviewees were initially approached by e-mail and further interviewed personally and by phone. After establishing the initial contacts, on-going revitalization processes were continuously monitored by phone, e-mail and media in the time span of five years between 2015 and 2020. The average number of repeated contacts with one interviewee represented nine interactions. In total, seven persons from six revitalization projects were interviewed. They encompassed executive managers, innovative leaders, founders/co-founders of not-for-profit organizations responsible for regeneration processes, networkers and other creative and knowledge workers representing the so-called bottom-up initiatives. The average length of practice in urban revitalization endeavours among the interviewees was eight years (in 2020). Several interviewees were involved in more than one project from the sample and acted as knowledge brokers.

In addition, primary observatory data was gathered in the form of notes and audio-visual recordings from visited events related to the revitalization projects. In total, almost hundred events organized by explored organizations, mostly in Bratislava, but also in Zilina and Kosice, were personally visited during the study. A very valuable addition was a participation in conferences, workshops and various events organized by local, regional and international institutions such as city councils, Slovak government, chambers of commerce and EU structures. The intention was to analyse, compare and summarize best practices in using knowledge tools, knowledge transfer and knowledge management within urban regeneration initiatives implementation. The secondary research, comprising the analysis of available printed and electronic documents related to the revitalization projects and official public reports (Ministry of Culture of the Slovak republic), was used in order to complement the primary research. This included also regular monitoring of the revitalization projects' web pages, local and national newspapers such as Trend, Profit, Forbes, Hospodárske noviny, SME, The Slovak Spectator, Journal SaB - Stavebníctvo a bývanie, CE.ZA.AR prize and others. 
Table 2 Codes for processing textual data

\begin{tabular}{|c|c|c|c|c|c|c|}
\hline \multicolumn{3}{|c|}{ categories/codes } & \multicolumn{4}{|l|}{ specification } \\
\hline 1 & \multicolumn{2}{|c|}{ actors \& activities } & \multicolumn{4}{|c|}{$\begin{array}{l}\text { presentation of main actors involved in the regeneration process (leaders and their } \\
\text { teams) and activities connected with the revitalization effort }\end{array}$} \\
\hline 2 & \multicolumn{2}{|c|}{$\begin{array}{l}\text { history \& revitalization of the } \\
\text { building }\end{array}$} & \multicolumn{4}{|c|}{$\begin{array}{l}\text { identification of the original purpose of the buildings, their history and the type of } \\
\text { revitalization processes }\end{array}$} \\
\hline 3 & \multicolumn{2}{|c|}{ adaptive re-use } & \multicolumn{4}{|c|}{$\begin{array}{l}\text { transformation of the buildings' original purpose into new usage alternatives after } \\
\text { the accomplished regeneration }\end{array}$} \\
\hline 4 & \multicolumn{2}{|c|}{ programming } & \multicolumn{4}{|c|}{$\begin{array}{l}\text { the structure and frequency of offered events and activities in the revitalized venues } \\
\text { after their adaptive re-use }\end{array}$} \\
\hline 5 & \multicolumn{2}{|c|}{ target group(s) } & \multicolumn{4}{|c|}{$\begin{array}{l}\text { identification of target group(s) of the revitalized venues based the proposed } \\
\text { activities and program }\end{array}$} \\
\hline 6 & \multicolumn{2}{|c|}{$\begin{array}{l}\text { knowledge } \\
\text { management }\end{array}$} & \multicolumn{4}{|c|}{$\begin{array}{l}\text { types of knowledge transfer, internal and external communication channels, involved } \\
\text { actors, formalized and informal knowledge management processes }\end{array}$} \\
\hline 7 & \multicolumn{2}{|l|}{ financing } & \multicolumn{4}{|c|}{$\begin{array}{l}\text { sources of funding used for the regeneration, financial structure, financial vs. non- } \\
\text { financial inputs, budgeting }\end{array}$} \\
\hline 8 & \multicolumn{2}{|c|}{ stakeholders' feedback } & \multicolumn{4}{|c|}{$\begin{array}{l}\text { opinions and reactions of stakeholders to the performance of the revitalized urban } \\
\text { venues after their regeneration }\end{array}$} \\
\hline \multicolumn{7}{|c|}{ Table 3 Factors influencing the knowledge management in the sample } \\
\hline \multicolumn{3}{|c|}{$\begin{array}{c}\text { organization } \\
\text { type }\end{array}$ organization size } & $\begin{array}{l}\text { management } \\
\text { style }\end{array}$ & $\begin{array}{l}\text { environment } \\
\text { type }\end{array}$ & $\begin{array}{l}\text { knowledge } \\
\text { type }\end{array}$ & $\begin{array}{l}\text { knowledge } \\
\text { processes }\end{array}$ \\
\hline & $\begin{array}{l}\text { civil } \\
\text { anizations, } \\
\text { an cultural } \\
\text { centres }\end{array}$ & $\begin{array}{l}\text { small (up to } 15 \\
\text { workers) }\end{array}$ & $\begin{array}{l}\text { informal, low } \\
\text { bureaucracy, } \\
\text { low power } \\
\text { distance, high } \\
\text { trust }\end{array}$ & $\begin{array}{l}\text { learning } \\
\text { organization, } \\
\text { middle degree } \\
\text { of uncertainty, } \\
\text { volunteering }\end{array}$ & tacit, explicit & $\begin{array}{l}\text { leadership, } \\
\text { routines, } \\
\text { acquiring, } \\
\text { capturing, } \\
\text { sharing }\end{array}$ \\
\hline
\end{tabular}

\subsection{Data processing}

A manual coding was applied in order to process the textual data from the in-depth interviews transcripts and gathered documents. Prior to the interviewing process, a coding scheme was developed by standardizing the units of text. These units represented also the final structure of interviews (Table 2): Actors and activities; history and revitalization of the building; adaptive re-use; programming; target group(s); knowledge management; financing; and stakeholders' feedback.

Nevertheless, the large amount of data and demanding conversion processes required a complex and systematic approach in data selection, analysis and comparison of the examined phenomena. The data processing involved detailed analysis and comparison of selected categories in all the examined projects, identifying similar and different characteristics. It was assumed that only an integrated framework and unified criteria could lead to design of the intended knowledge management model as an effective tool for mapping the knowledge transfers within the culture-based urban regeneration initiatives.

After processing all the gathered information, a multi-factor knowledge management model for the culture-based urban regeneration was developed. During this process, diverse factors influencing the knowledge management practices in the sample were summarized (Table 3).

\section{The multi-factor knowledge management model}

The tailor-made multi-factor knowledge management model [13-14] was developed for a specific purpose - the culture-led urban regeneration of unused buildings or venues - with the aim of mapping the knowledge transfer within this particular environment. The model is grounded in Nonaka and Takeuchi's SECI model (Socialization-Externalization-CombinationInternalization) suggesting that knowledge sharing can support creation of a new knowledge since it can transfer both tacit knowledge and explicit knowledge into the organizational knowledge [41]. The SECI model was selected as the most suitable one for application in the environment of urban revitalization after having researched and analysed several types of available knowledge management models. It highlights the need of assessing all the consecutive phases of knowledge conversion in order to achieve a desired goal: the efficient and effective knowledge management and communication between all the actors (team leaders, team members and stakeholders). 


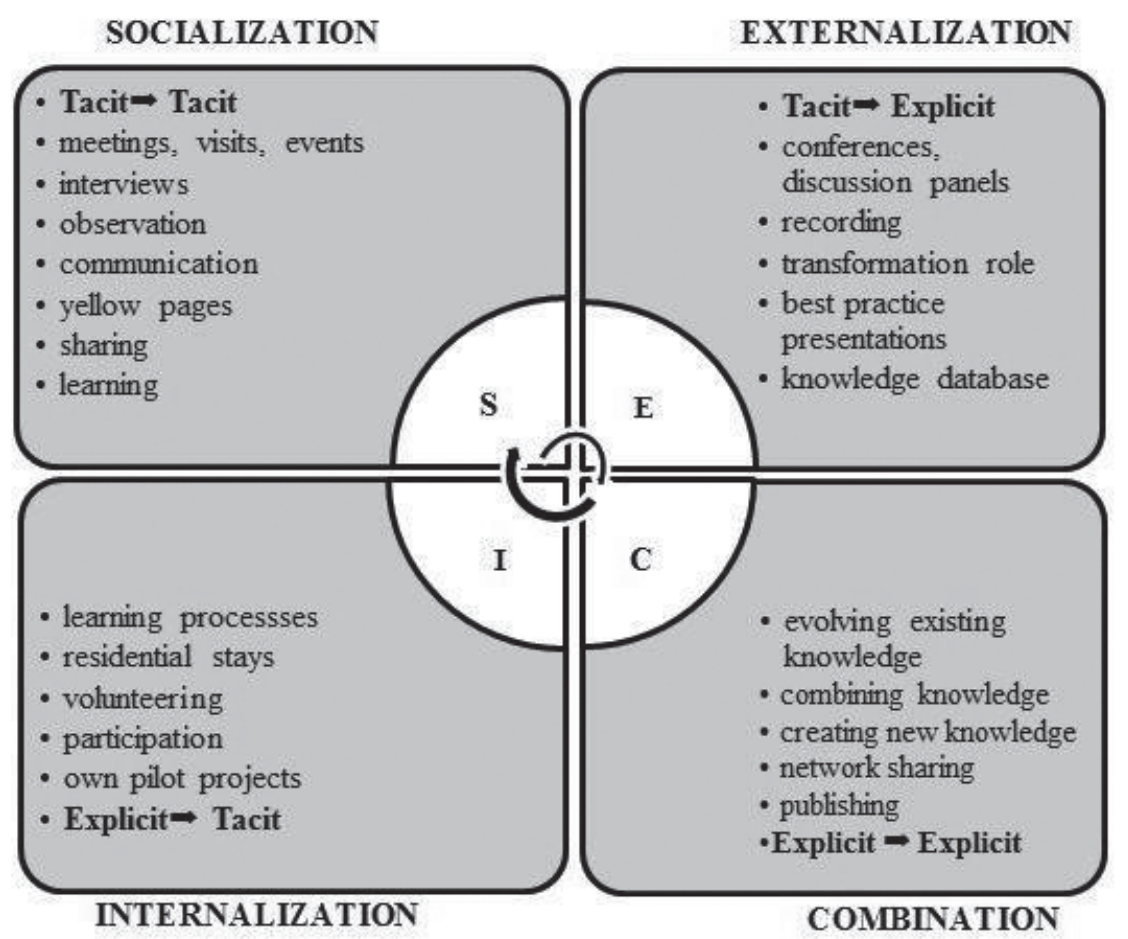

Figure 1 Adjusted SECI model for application within the culture-based urban regeneration, based on Nonaka and Takeuchi's SECI model, [41]

In the first stage, different phases of the SECI model were applied to the knowledge management processes implemented within the examined projects of the culture-based urban regeneration (Figure 1). While individual stages of the SECI model stayed identical, specific elements within them were modified or newly defined based on this research.

\section{- Socialization}

The initial phase of the SECI model runs within the context of culture-based regeneration projects at several levels:

1. Among the team members involved in regeneration projects (internally) and all stakeholders (externally) on the local and regional level.

2. Among the teams of non-profit organizations registered in the Slovak network of independent cultural centers ANTENA (Network of cultural centres and organisations operating in the field of independent arts and culture in Slovakia) on the national level.

3. Among the members of the international network T.E.H. - Trans Europe Halles (International network for grassroots cultural centres focused on repurposing abandoned buildings for arts, culture and activism), as the oldest and largest organization assisting in sharing experiences among European independent cultural centers on the international level.

The most effective and frequently used tools were visits, meetings, stays and presentations focused on identifying, learning and sharing the best practices experineced within diverse revitalization projects.

\section{- Externalization}

The phase of externalization includes organization of meetings, workshops, conferences and panel discussions with the use of explicit visual forms of knowledge management as pictures, videos, photographs, data presentations, statistics and reviews of visitors, or even documentaries from the reconstruction phases of the revitalized venues. Since most of the urban regeneration projects are run by the non-profit organizations supported via public funding schemes, the externalized knowledge is mandatory available on their websites, as well, as a tool for ensuring the transparent operations within the subsidized projects.

\section{- Combination}

Authors assume that the potential of the combination phase lies in implementation of information and knowledge exchange platforms, inspiration, adoption of successful ideas and creation of the new ones. However, it is important to be aware that the universal rules do not always work and specific local or regional differences should be considered. Therefore, it is recommended to achieve a high diversity and flexibility in activities such as program offers, entire dramaturgy, seasonal character, stakeholders' input and volunteers' involvement.

\section{- Internalization}

The final phase of the SECI model - internalization - appears to be an opportunity for creating a certain added value to all the previous stages. Within this phase it is expected to implement the skills and knowledges developed during the effective learning processes 


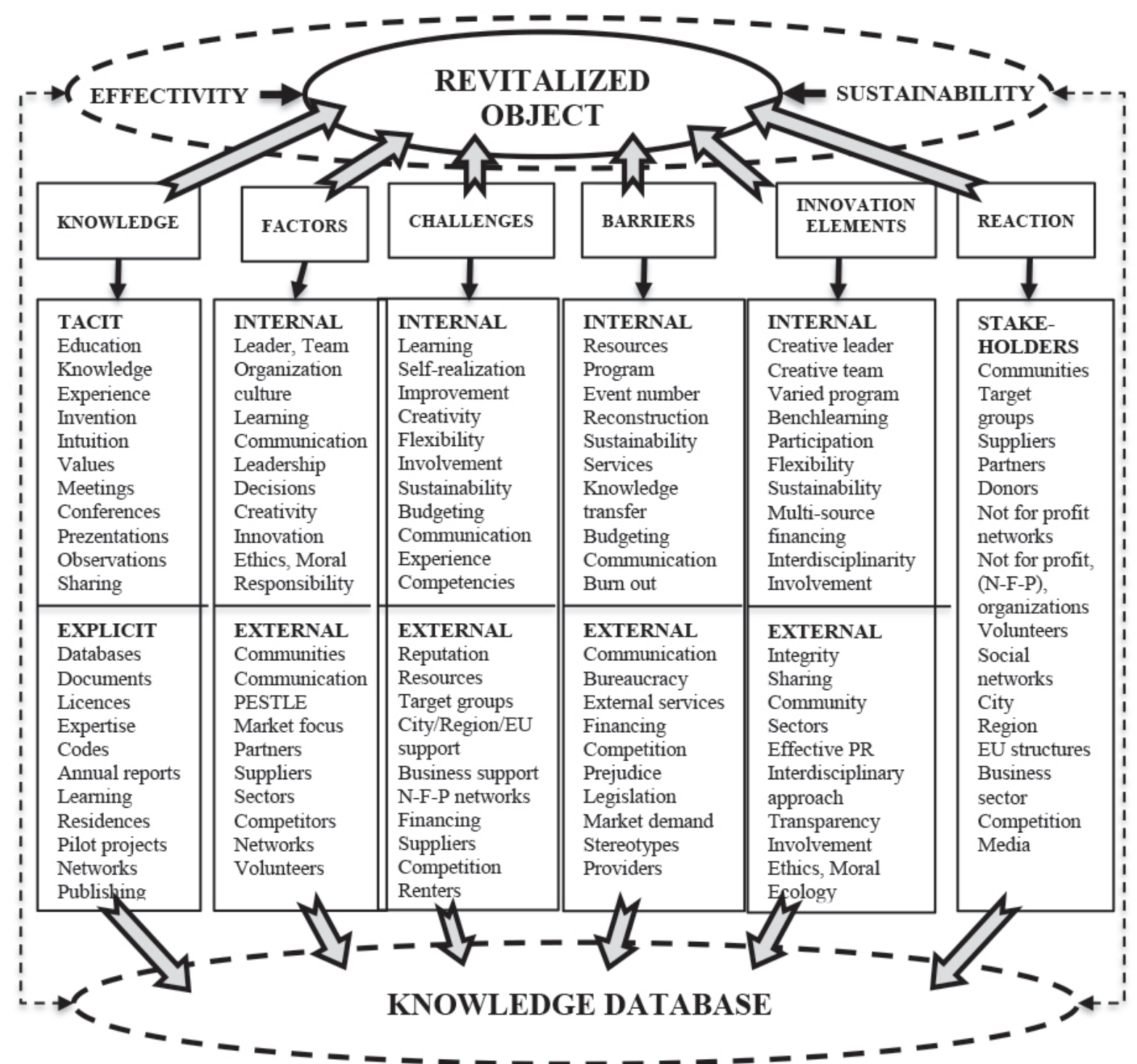

Figure 2 The multi-factor knowledge management model for the culture-based urban regeneration

in previous stages, active participation or creative and innovative approach. Through such activities as workshops, residential stays, visits, volunteering and regular communication, the project teams should succeed in developing and managing their own revitalization projects, with all the signs of transparency, effectiveness and sustainability.

In the second stage, the original spiral SECI model was enlarged for the purpose of this particular research by adding eight specific elements: Revitalized object, knowledge database, knowledge, factors, challenges, barriers, innovative elements and reaction. Its modification required a careful selection of processes and tools, which reflect the particular urban context of the examined organizations involved in the culture-based urban regeneration projects (Figure 2).

\section{- Revitalized object}

Revitalized object represents unused buildings or venues, which undergo a revitalization process. It should be noted that most of the urban regeneration projects are carried out as non-profit and bottom-up initiatives based on creative ideas and social innovation. The knowledge sharing from one project to another is a common modus operandi in this field. The main objective of the regeneration process is to bring unused buildings and venues back to life. In most cases the revitalization process involves a change of the original use of buildings into the new usage alternatives. The focus here was on those projects whose new purpose is linked to culture.

\section{- Knowledge database}

The knowledge database represents a generator of human knowledge coming from different sources, disciplines and areas. It is a bank of data, contacts, procedures, proposals, processes and solutions related to cases and issues that are treated or have been treated in the past. The knowledge database is an effective tool 
especially in view of sustainability. Once the revitalization project is accomplished, the creative leaders may not present anymore, yet the needed knowledge remains available to other team members. However, the essential condition for the effective performance of knowledge database is its on-going maintenance. The data has to be gathered, sorted and stored in order to be available when needed. In addition, it requires the ability of all the involved workers to correctly identify the data, find, implement and share them.

\section{- Knowledge}

According to Wiig [42], knowledge - as a unique and very valuable source owned by an organization - is tightly connected to creation of an outstanding competitive advantage. Bures [43] highlights the unique value and character of knowledge as it possesses such attributes which are absent in other resources. However, its specific character of being unstable, unquantifiable, intangible and inseparable of its bearer makes it vulnerable at the same time. Therefore, the key factor of knowledge exploitation is its transfer and implementation. In the context of this study the focus was on transmission of both the tacit and explicit knowledge among team members, as well as from the previous regeneration projects to the new ones.

\section{- Factors}

In order to achieve desired outcomes in any type of organization, it is necessary to define and analyse both internal and external factors influencing the organizational performance. Several specific factors have to be considered in the case of urban regeneration projects, in particular the effective team management, creativity, innovation, learning environment and organizational culture. It is also necessary to highlight the importance of brave visions, complex and conceptual thinking, ethics, as well as open and effective communication with all the stakeholders: communities, municipality, regional and state institutions, businesses, media, European Union institutions, foundations, networks, etc.

\section{- Challenges}

Managers of the culture-based urban regeneration projects face several particular challenges given by the specific nature of this type of endeavours. Their ambition and mission are to contribute to the management of public matters, enhancement of the bottom-up activities, changes in stereotypes and replacement of the nonfunctional usage solutions with innovative and creative alternatives with inclusive and environmental emphasis. Expected results include goodwill, successful intersectoral cooperation and the attraction of diverse target groups and volunteers.

\section{- Barriers}

Barriers within the process of culture-led urban regeneration involve mainly administrative and functional obstacles, constraints, risks and limits. Basically, they can be split into two categories: internal barriers (lacking personal, insufficient material and financial resources, limitations in program offers or frequency of events) and external barriers (communication with stakeholders, competition on the market, low institutional support, biases). The impact of both has an equal importance and deserves attention in the urban revitalization processes in order to avoid the risk of failure.

\section{- Innovation elements}

Defining and implementing innovative elements within the culture-led urban regeneration processes appears to be a crucial activity for achieving demanding conversions of the venues, as well as for ensuring their sustainability. The innovative elements are often results of the bottom-up initiatives proposed by visionary leaders. Their common features are interdisciplinarity, holistic perspective, team learning, transparency, multisource financing, synergy and tight public links.

\section{- Reaction}

Reaction within the model stands for the feedbacks received from all stakeholders. The ambition of most urban-regeneration projects lies in offering a unique vision, innovative added value and the meaningful transformation of unused buildings and venues into vibrant cultural and creative centres. Such an ambition addresses diverse publics including municipalities, regional and state institutions, not-for-profit organizations, businesses, artists, citizens, tourists and possibly others. It is important to monitor the reactions of all the concerned groups in order to ensure the acceptance and sustainability of the new purpose of revitalized industrial and cultural heritage.

As depicted at the scheme, the revitalized object and knowledge database represent two poles of the multi-factor knowledge management model. They interfere with the remaining elements within repeated knowledge transfers. The ultimate aim of the model is to achieve effectivity and sustainability of urban regeneration endeavours by ensuring the adequate knowledge transfer.

\section{$5 \quad$ Findings}

Provided that the focus was on urban regeneration, the regional capitals - Bratislava, Zilina and Kosice - from western, central and eastern part of Slovakia were included into the study. Two of the cities from our sample - Bratislava and Kosice - have already been recognized as "Creative Cities" and monitored within the Cultural and Creative Cities Index (CCC) established by the European Commission in 2015 (Table 4).

Bratislava registers the highest score in Slovakia within the C3 overall index and ranks $9^{\text {th }}$ among the 
Table 4 Cultural and Creative Cities Index 2019 of the Slovak cities in the sample

\begin{tabular}{ccccccc}
\hline creative city & $\begin{array}{c}\text { C3 index } \\
\text { (overall })\end{array}$ & $\begin{array}{c}\text { cultural } \\
\text { vibrancy }\end{array}$ & $\begin{array}{c}\text { creative } \\
\text { economy }\end{array}$ & $\begin{array}{c}\text { enabling } \\
\text { environment }\end{array}$ & $\begin{array}{c}\text { cities / } \\
\text { group of cities }\end{array}$ \\
\hline Bratislava & $31.9\left(9^{\text {th }}\right)$ & $25.7\left(12^{\text {th }}\right)$ & $44.4\left(1^{\text {st }}\right)$ & $19.3\left(33^{\text {rd }}\right)$ & $\mathrm{L}^{*}$ & 40 \\
Kosice & $13.2\left(76^{\text {th }}\right)$ & $16.1\left(71^{\text {st }}\right)$ & $9.6\left(72^{\text {nd }}\right)$ & $14.9\left(66^{\text {th }}\right)$ & S-M** & 79 \\
\hline
\end{tabular}

* L group: 250000 - 500000 inhabitants

** S-M group: 50000 - 250000 inhabitants

based on [44]

40 ranked European cities with 250000 to 500000 inhabitants. Bratislava gets the top spot on "Creative Economy" in its group thanks to its leading position on New Jobs in Creative Sector and its good performance on Creative \& Knowledge-based Jobs $\left(8^{\text {th }}\right)$. It also performs well on "Cultural Vibrancy" reaching the $12^{\text {th }}$ position in the group.

Among the other ranked Slovak cities, all with fewer than 250000 inhabitants, Kosice reaches the overall $76^{\text {th }}$ position and performs best on "Enabling Environment", ranking the $66^{\text {th }}$ among the 79 ranked European cities in the smallest population group. As in other European countries, capitals generally lead on "Creative Economy" but non-capitals, mostly medium-sized, do better on "Cultural Vibrancy" [44-45]. Being the only Slovak member of the UNESCO Creative Cities Network, Kosice becomes a hotspot for media arts thanks to its strong position in the ICT sector and a young vibrant creative community [35].

Most of the culture-based urban regeneration projects, included into the sample, represented cases where the original purpose of the venue was transformed into a new one, with a partial exception of Stara trznica (City Market Hall) in Bratislava and Zilina-Zariecie (Local Train Station) in Zilina. Diverse original purposes of the examined venues shifted into new creative urban centres satisfying the needs of various target groups: young people, families, seniors, creative artists, students and tourists. Moreover, those centres were expected not only to provide multi-genre cultural events and additional services, but also to preserve the historical value of the revitalized industrial and cultural heritage (buildings and its facilities).

Five of the six examined urban revitalization projects have been able to sustain their original intention and keep serving for cultural purposes. However, one project - IC Culture Train (Vysne Opatske) in Kosice did manage to revitalize the unused building but did not succeed in maintaining its cultural usage. As a result, the revitalized building serves as a grocery store today. Generally, the examined revitalization initiatives represented a continuous regeneration effort performed in several consecutive stages. The regeneration stages were carried out as follows:

(1) KC Dunaj: 2010 - 2012 Main reconstruction, 2013

- 2016 Interior revitalization and gallery, 2019

Interior remodelling.

(2) Stara Trznica: 2013 - 2015 Main Reconstruction with parallel Saturday markets in 2015, 2016 2019 Interior remodelling, 2017 Exterior square revitalization, 2018 - ongoing vivid square revitalization project.

(3) Stanica Zilina-Zariecie: 2003 - 2009 Main reconstruction, 2019 Remodelling after the fire.

(4) Nova Synagoga: 2011 - 2017 Main reconstruction with parallel cultural events, 2018 ongoing contemporary constructions upon exhibitions and events.

(5) IC Culture Train: 2005 - 2008 accomplished regeneration. The cultural purpose was not sustained.

(6) Tabacka Kulturfabrik: 2009 - 2015 Main reconstruction, 2020 Art garden revitalization.

The results of the research are very consistent within the whole sample in terms of the performance across the eight examined categories (textual codes). All the revitalized buildings possessed a historical value and were the property either of the municipality, region, state or church. The revitalization process involved the adaptive re-use of industrial or cultural heritage that gave a new use to obsolete, underused or misused buildings. The new purpose of the revitalized buildings was ensured via written agreements on their future usage alternatives between their owners and new operators. This approach is in line with Landry's [27] vision of the "Creative City", understood as a method of strategic urban planning where urban innovators are requested to reinvent the city as a lively centre of creativity laying the foundations for improving quality of life of the citizens.

Another common feature of all the analysed cases was implementation of the transparent multi-source financing models, perceived as a guarantee of the projects sustainability. In addition, the permanent effort to monitor stakeholders' and visitors' feedback, together with open and effective communication and long-term cooperation with municipalities and the business sector, helped in fulfilling the innovative and creative visions of the revitalization projects. In particular, the long lasting collaboration with municipalities in developing creative cities has been pointed out by Landry [27] who emphasizes the need of ensuring the facilitating factors that propel the creativity of creative people. These factors include infrastructure, research capacity, venture capital investment or clusters of producers. 
Table 5 Comparison and summary of the examined categories in the revitalized venues

\begin{tabular}{|c|c|c|}
\hline & categories & comparison and summary \\
\hline 1 & actors \& activities & $\begin{array}{l}\text { Creative, innovative and interdisciplinary individuals, educated professionals with experiences } \\
\text { and skills. They worked in organizations with strong culture and vision and used a conceptual } \\
\text { thinking leading to the effective performance and sustainability. }\end{array}$ \\
\hline 2 & $\begin{array}{l}\text { history \& building } \\
\text { revitalization }\end{array}$ & $\begin{array}{l}\text { Each of the regenerated venues had a distinct original purpose and historical value, though, after } \\
\text { the reconstruction and conversion they all served as cultural, creative and community centres. }\end{array}$ \\
\hline 3 & $\begin{array}{l}\text { adaptive } \\
\text { re-use }\end{array}$ & $\begin{array}{l}\text { Buildings conversion was directed towards community cultural centres, independent culture, } \\
\text { social events, markets and creative industries including creative hubs or labs. }\end{array}$ \\
\hline 4 & programming & $\begin{array}{l}\text { After the conversion, all the revitalized objects were characterized by multi-genre programming, } \\
\text { regular markets, creative and innovative workshops, charity events, various services as shops, } \\
\text { bars and cafes. }\end{array}$ \\
\hline 5 & target group(s) & $\begin{array}{l}\text { Target groups encompassed broad age and interest spectrum, social categories, locals and visitors } \\
\text { and the representatives of all sectors. }\end{array}$ \\
\hline 6 & $\begin{array}{l}\text { knowledge } \\
\text { management }\end{array}$ & $\begin{array}{l}\text { Several types of knowledge transfer were identified: external knowledge transfer between } \\
\text { different revitalization projects across Europe (based on networking), internal knowledge } \\
\text { transfer via people working on more than one project and intra-team knowledge transfer via the } \\
\text { transmission of individual knowledge into organizational knowledge. The project leaders shared } \\
\text { their knowledge in managing the urban revitalization with their teams and also with other urban } \\
\text { regeneration projects. }\end{array}$ \\
\hline 7 & financing & $\begin{array}{l}\text { Multi-source transparent financing models aimed at achieving sustainability of the revitalization } \\
\text { projects were implemented. }\end{array}$ \\
\hline 8 & $\begin{array}{l}\text { stakeholders' } \\
\text { feedback }\end{array}$ & $\begin{array}{l}\text { Declared continual support, long-term visions, best practices status, awards for development, } \\
\text { community involvement, effective communication, transparency and sustainability. }\end{array}$ \\
\hline
\end{tabular}

In spite of the fact that the revitalized venues were located in different cities and regions of Slovakia (considering possible demographic and economic deviations), the summarized findings indicate a prevailing compliance visible in all the analysed projects. Table 5 summarizes the outputs gained after the assessment and comparison of all the urban regeneration projects included into the sample.

In view of the knowledge transfer, it was crucial that the organizations implementing the revitalization projects were active members of several national and international platforms/networks for sharing knowledge and experiences related to urban regeneration initiatives, e.g. ANTENA (Network of cultural centres and organisations operating in the field of independent arts and culture in Slovakia) and T.E.H. (Trans Europe Halls - International network for grassroots cultural centres focused on repurposing abandoned buildings for arts, culture and activism). This was particularly important in view of the external knowledge transfer (both explicit and tacit) between different revitalization projects and cases. In addition, an internal knowledge transfer was identified and ensured via people who worked on more than one project (usually two projects) and transferred their knowledge gained in one project to the other one. Finally, an intra-team knowledge transfer was identified in the form of the transmission of individual tacit knowledge into organizational knowledge. Especially, the transfer of tacit knowledge from different sources was significant for succeeding in urban regeneration effort.

As a result, knowledge managers, together with their teams and other stakeholders, underwent the processes of gradual reconstruction and regeneration of dilapidated and unused heritage buildings and actively anticipated their adaptive re-use as vivid cultural urban centres. These successful urban transformations, encompassing innovative learning processes and effective knowledge management, caught the attention of public, as well as experts and resulted in attributing several Slovak and foreign awards.

\section{Conclusions}

Common success factors for an effective and efficient knowledge management were identified within the culture-based urban regeneration under the concept of a creative city. All the projects included into the study showed almost identical characteristics in the examined categories. Their primary intention was to convert dilapidated and unused buildings into vibrant cultural centres offering a rich multi-genre program for diverse target groups. This research confirmed that creative and innovative approach within knowledge management enables overcoming barriers and obstacles in the revitalization of urban industrial and cultural heritage, based on the bottom-up initiatives and effective knowledge creating-sharing cycle. It recognized that the effective knowledge transfer is a key element for achieving a successful urban regeneration, based on the adaptive re-use of unused venues with the aim of developing creative quarters and cities. Considering the fact that knowledge management involves a significant multidisciplinary character, a complex and holistic approach is suggested for an effective 
knowledge management within the culture-based urban regeneration initiatives.

The proposed multi-factor knowledge management model served to map knowledge management processes in culture-based urban regeneration projects in three Slovak cities. Nevertheless, the model can be applied to all the cases of revitalization of unused, respectively inappropriately used urban buildings and their adaptive re-use for cultural purposes. It highlights and recommends the correct usage of knowledge management tools for teams and organizations involved in the cultureled urban revitalization. The knowledge that is not well managed and shared evaporates easily, especially the tacit knowledge that resides in the minds of people and is accumulated over time, which must be shared. Hence, the knowledge sharing is considered to be the crucial element for an effective knowledge management.

The attention should be paid especially to the knowledge database (serving as a basis of human knowledge, procedures, data and solutions from various disciplines and fields), which constitutes the indispensable ground for knowledge utilization, as well as the knowledge transfer. The authors are convinced that only permanent creation, distribution, storing and sharing of knowledge, among creative knowledge workers and other involved participants, ensure that the knowledge management becomes an effective tool for achieving a successful culture-based urban revitalization. Project leaders together with their teams demonstrated the ability to learn and share valuable knowledge and experiences coming not only from their previous activities but from experiences of their Slovak or foreign peers, as well.

The authors believe that the creative, innovative and interdisciplinary approach, together with the bottom-up activities, focused on the multi-functional usage of revitalized venues contributed to strengthening their genius loci while serving a new cultural purpose. In addition, it is believed that the adaptive re-use of obsolete, underused or misused heritage buildings enhances the potential of urban areas for becoming vivid creative quarters and fosters regional development based on the creative economy.

The limitations of this study consist in lacking comparison of knowledge management practices in similar culture-based urban revitalization projects under the concept of creative city. This is due mainly to the limited research carried out in the concerned area. Therefore, a further research is needed in order to confirm or debate these findings.

\section{References}

[1] TAJTAKOVA, M. The arts and culture in the knowledge era. In: 7th International Workshop on Knowledge Management: proceedings. 2012. ISBN 978-8089-306-183, p. 1-7.

[2] SOUSA, M. Open innovation models and the role of knowledge brokers. ARK Knowledge Management Insight. 2008, p. 18-22 [online] [accessed 2018-9-12]. Available from: http://citeseerx.ist.psu.edu/viewdoc/ download?doi=10.1.1.457.2055\&rep=rep1\&type $=$ pdf

[3] FLORIDA, R. The rise of the creative class: and how it's transforming work, leisure, community and everyday life. New York: Basic Books, 2002. ISBN 978-0465024773.

[4] LEVICKAITE, R., REIMERIS, R. A pentagon of creative economy / Kurybos ekonomikos penkiakampis (in Lithuanian). Coactivity: Philosophy, Communication / Santalka: Filosofija, Komunikacija [online]. 2011, 19(1), p. 83-91. ISSN 2029-6320, eISSN 2029-6339. Available from: https://doi.org/10.3846/coactivity.2011.09

[5] HOWKINS, J. The creative economy: how people make money from idea. 2. ed. London: Penguin Business, 2013. ISBN 9780713994032.

[6] CAVES, R. Creative industries: contracts between arts and commerce. Cambridge: Harvard University Press, 2002. ISBN 978-0674008083.

[7] HARTLEY, J. Creative industries. Wiley-Blackwell Publishing, 2005. ISBN 978-1-405-10147-9.

[8] LANDRY, C., BIANCHINI, F. The creative city. Paper no. 12. London: Demos in association with Comedia, 1995. ISBN 1898309167.

[9] RENZ, E. Business models and the creative city: Amsterdam's knowledge mile in the limelight. Hogeschool van Amsterdam, Media, Creatie en Informatie, CREATE-IT Applied Research, Research Group Crossmedia, Supervisor VAN VLIET, H., 2015 [online] [accessed 2020-10-12]. Available from: https://www.hva.nl/create-it/ gedeelde-content/publicaties/ publicaties-algemeen/crossmedia/paper-erich-renz.html

[10] EUROPEAN CULTURAL PARLIAMENT. Lisbon Agenda Research Group. Culture, the heart of the knowledgebased economy. The strategic use of culture in the European project. Tuscany, 2006 [online] [accessed 2020-10-12]. Available from: http://www.kulturparlament.com/wp-content/uploads/2011/05/ECP-EU-strategic-use-ofculture-030906-final.pdf

[11] EUROPEAN COMMISSION. Unlocking the potential of cultural and creative industries. Green paper. Brussels, 27.4.2010 $\operatorname{COM}(2010) 183$ final [online] [accessed 2020-10-12]. Available from: https:/eur-lex.europa.eu/legalcontent/EN/TXT/PDF/?uri=CELEX: 52010DC0183\&from=EN 
[12] PORUMB, E. M., IVANOVA, N. V. Development through knowledge economy: Cluj-Napoca - European smart city. Management Dynamics in the Knowledge Economy. 2014, 2(3), p. 453-461. ISSN 2286-2668.

[13] OLEJAROVA, M. Knowledge management and learning in urban revitalization processes of selected non-profit cultural organizations in Slovakia. In: 20th International Conference on Interactive Collaborative Learning and 46th International Conference on Engineering Pedagogy ICL 2017: proceedings. 2017.

[14] OLEJAROVA, M., TAJTAKOVA, M. Knowledge management within culture-based urban regeneration projects in Slovakia. In: 13th International Workshop on Knowledge Management "Knowledge: Measurement, Evaluation and Interpretation": proceedings. 2018. ISBN 978-80-89306-37-4, p. 98-108.

[15] TAJTAKOVA, M., OLEJAROVA, M. The role of knowledge brokers in culture-led urban revitalization. In: 14th International Workshop on Knowledge Management "Knowledge Workers in the Knowledge Era": proceedings. 2018. ISBN 978-80-89306-41-1, p. 133-139.

[16] SCOTT, J. A. The cultural economy of cities. International Journal of Urban and Regional Research [online]. 1997, 21(2), p. 323-339. eISSN 1468-2427. Available from: https://doi.org/10.1111/1468-2427.00075

[17] FLORIDA, R. Cities and the creative class. London: Routledge, 2005. ISBN 0-415-94887-8.

[18] VAN DER BORG, J., RUSSO, A. P. The impact of culture on the economic development of cities. Rotterdam: European Institute for Comparative Urban Research, Erasmus University Rotterdam, 2005.

[19] RODRIGUES, M., FRANCO, M. Measuring the performance in creative cities: proposal of a multidimensional model. Sustainability [online]. 2018, 10(11), 4023. eISSN 2071-1050. Available from: https://oi.org/10.3390/ su10114023

[20] POWER, A. J., SCOTT, D. Culture, creativity and urban development. In: Handbook of local and regional development. PIKE, J., RODRIGUEZ-POSE, A., TOMANEY, A. (eds.). Routledge: Abingdon-on-Thames, UK, 2011. ISBN 9780415548311, p. 162-171.

[21] UNESCO. Creative cities of UNESCO for sustainable development. 2018 [online] [accessed 2020-7-12]. Available from: https://en.unesco.org/creative-cities/sites/creative-cities/files/unesco_uccn_en_180530_final.pdf

[22] VAN DEN BERG, L. Urban systems in a dynamic society. Aldershot: Gower Pub Co, 1987. ISBN 978-0566052514.

[23] STERN, M. Testimony of Mark J. Stern. Social impact of the arts project. 2000 [online] [accessed 2018-09-12]. Available from: http://www.ssw.upenn.edu/SIAP

[24] SHANG-YING, CH. Constructing cultural indicator system of Kaohsiung City, Taiwan. In: 9th International Conference of Arts and Cultural Management A.I.M.A.C.: proceedings. 2007.

[25] STASIULIS, N. The idea of the creative society and the development of creative industries. Economics and Sociology [online]. 2017, 10(2), p. 217-226 [accessed 2020-7-12]. ISSN 2071-789X. Available from: https://doi.org/10.14254/2071-789X.2017/10-2/16

[26] PASTAK, I., KAHRIK, A. The impacts of culture-led flagship projects on local communities in the context of post-socialist Tallinn. Sociologicky Casopis / Czech Sociological Review [online]. 2016, 52(6), p. 963-990 [accessed 2018-09-12]. ISSN 0038-0288, eISSN 2336-128X. Available from: https://doi.org/10.13060/00380288.2016.52.6. 292

[27] LANDRY, C. The creative city. a toolkit for urban innovators [online] [accessed 2020-10-12]. London: Earthscan, 2008. ISBN 1-85383-613-3. Available from: https://doi.org/10.1080/23311975. 2015.1127744

[28] TUROK, I. Property-led urban regeneration: panacea or placebo? Environment and Planning [online]. 1992, 24(2), p. 361-379 [accessed 2020-7-12]. ISSN 0308-518X, eISSN 1472-3409. Available from: https://doi.org/10.1068/ a240361

[29] JAYNE, M. Culture that works? Creative industries development in a working class city. Capital and Class [online]. 2004, 84, p. 199-210 [accessed 2018-09-12]. ISSN 0309-8168, eISSN 2041-0980. Available from: https://doi.org/10.1177/030981680408400119

[30] EVANS, G. Measure for measure: evaluating the evidence of culture's contribution to regeneration. Urban Studies [online]. 2005, 42, p. 959-983 [accessed 2018-09-12]. ISSN 0042-0980, eISSN 1360-063X. Available from: https://doi.org/10.1080/00420980500107102

[31] SAGAN, I., GRABKOWSKA, M. Urban regeneration in Gdansk, Poland: local regimes and tensions between top-down strategies and endogenous renewal. European Planning Studies [online]. 2012, 20(7), p. 1135-1154 [accessed 2018-09-12]. ISSN 0965-4313, eISSN 1469-5944. Available from: https://doi.org/10.1080/09654313. 2012.674347

[32] TEMELOVA, J. Flagship developments and the physical upgrading of the postsocialist inner city: the Golden Angel project in Prague. Geografiska Annaler: Series B - Human Geography [online]. 2007, 89B(2), p. 169-181. eISSN 1468-0467. Available from: https://doi.org/10.1111/j.1468-0467.2007.00246.x

[33] PRATT, A. C. Creative cities: the cultural industries and the creative class. Geografiska Annaler: Series B Human geography [online]. 2008, 90(2), p. 107-117 [accessed 2018-09-12]. eISSN 1468-0467. Available from: https://doi.org/10.1111/j.1468-0467.2008.00281.x 
[34] MILES, S., PADDISON, R. Introduction: the rise and rise of culture-led urban regeneration. Urban Studies [online]. 2005, 42, p. 833-839 [accessed 2018-09-12]. ISSN 0042-0980, eISSN 1360-063X. Available from: https:// doi.org/10.1080/00420980500107508

[35] UNESCO. Creative cities network [online] [accessed 2020-08-02]. Available from: https://en.unesco.org/creativecities/

[36] UNESCO. Voices of the city. UNESCO creative cities moving towards the 2030 Agenda for Sustainable Development. 2019 [online] [accessed 2020-08-02]. Available from: https://en.unesco.org/creative-cities/sites/ creative-cities/files/16_pages_villes_creatives_uk_bd.pdf

[37] MONTALTO, V., TACAO MOURA, C., PANELLA, F., ALBERTI, V., BECKER, W., SAISANA, M. The cultural and creative cities monitor: 2019 edition [online] [accessed 2020-08-02]. Luxembourg: Publications Office of the European Union, 2019. ISBN 978-92-76-08807-3. Available from: https://doi.org/10.2760/257371.

[38] EUROPEAN COMMISSION. Cultural Heritage in Action. European Framework for Action on Cultural Heritage. 2020. [online] [accessed 2020-08-02]. Available from: http://www.cultureforcitiesandregions.eu/ culture/project

[39] APPLEYARD, M. How does knowledge flow? Interfirm patterns in the semiconductor industry. Strategic Management Journal, Special Issue: Knowledge and the Firm. 1996, 17(2), p. 137-154 [online] [accessed 2020-1012]. Available from: https://doi.org/10.1002/smj.4250171112

[40] MARTINI, L. Knowledge sharing in a creative city. In: International Conference on Knowledge Management ICKM 2016: proceedings [online] [accessed 2020-10-12]. 2016. p. 79-90. Available from: http://doi:10.1016/j. procs.2016.09.102

[41] NONAKA, I., TAKEUCHI, H. The knowledge-creating company? How Japanese create the dynamics of innovation. Long Range Planning [online]. 1996, 29(4), p. 592. ISSN 0024-6301. Available from: https://doi.org/10.1016/0024-6301(96)81509-3

[42] WIIG, K. Knowledge management: an emerging discipline rooted in a long history. Journal of Knowledge Management [online]. 1999, 1(4), p. 269-274 [accessed 2020-08-02]. ISSN 1367-3270. Available from: http://www.krii.com/ downloads/km_emerg_discipl.pdf

[43] BURES, V. Conceptual perspective of knowledge management. E and M: Economics and Management / E a M: Ekonomie a Management. 2009, 12(2), p. 84-96. ISSN 1212-3609.

[44] EUROPEAN COMMISSION. The Cultural and Creative Cities Monitor 2019. Country fact sheets 2019 - Slovakia [online] [accessed 2020-08-02]. Available from: https://publications.jrc.ec.europa.eu/repository/ bitstream/JRC117336/sk.pdf

[45] EUROPEAN COMMISSION. Cultural and creative cities monitor. Composite indicators [online] [accessed 2020-08-02]. Available from: https://composite-indicators.jrc.ec.europa.eu/cultural-creative-cities-monitor/ performance-map 